\title{
Hutchinsonianism: A Counter-Enlightenment Reform Movement
}

\begin{abstract}
The followers of the natural philosopher John Hutchinson developed a religious movement which produced one of the most notable schools of eighteenth-century Anglican thought. This paper describes Hutchinsonianism's position, firstly, in relation to other religious movements of the period. It sites it within a temporally specific spectrum of ecclesiastical positions and also offers a more general description of its character. To be more specific, there is discussion of the nature of the phenomenon of High Churchmanship and evangelicalism in this period and a justification of the use of the term "reform movement." In the latter part of the paper, Hutchinsonianism is placed within the general intellectual currents of its age. In the course of this discussion attention is drawn to previously underemphasized areas of Hutchinsonian interest, notably the history of religion. However, more importantly, this part of the paper uses Hutchinsonianism to discuss and clarify the use of the terms "Enlightenment" and "Counter-Enlightenment" in the study of English intellectual history.
\end{abstract}

The dismissal by the future bishop of Worcester, Richard Hurd, of the defence of Hutchinsonianism by the future bishop of Norwich, George Horne, as refutable by any Cambridge undergraduate, discloses more about the party feeling which Hutchinsonianism engendered than about the contemporary credibility of the system ${ }^{1}$ : the quantity of ink spilled in combating the Hutchinsonians reveals the difficulty of the task. The contempt of later periods, however, was genuine. Hutchinsonianism was ignored; and if individual Hutchinsonians attracted biographical attention, their doctrines were considered "curious" and "singular," or, more bluntly, "additions to the sum of human error." In recent years the movement has attracted more and sympathetic attention. It has been recognized as having had a significant contemporary following and identified as the most notable grouping for much of that period in the history

1. Hurd to Thomas Balguy, 14 March 1753, The Early Letters of Bishop Richard Hurd 17391762, Church of England Record Society Publications, no. 3, ed. S. Brewer (Woodbridge, Suff.: Boydell Press, 1955), 244-6, 244.

2. John Hill Burton, Lives of Lord Simon Lovat, and Duncan Forbes, of Culloden ... (London, 1847), 346.

3. Quoted by Gavin White in "Hutchinsonianism in Eighteenth-Century Scotland," Records of the Scottish Church History Society 21, pt. 2 (1982): 157-69, 166.

C. D. A. Leighton is a lecturer in British history, Bilkent University, Ankara. 
of High Churchmanship between the decline of the Non-Jurors and the rise of the Tractarians. ${ }^{4}$ There has, accordingly, been some effort made to describe and explain the anti-Newtonian natural philosophy, which can be regarded as chiefly constituting the Hutchinsonianism ${ }^{5}$ of at least John Hutchinson himself. ${ }^{6}$ However, the content of such studies in the history of science themselves reveal the need for complementary studies in wider intellectual history and, in particular, in religious history. ${ }^{7}$ Certainly, if what is considered is the Hutchinsonian movement, rather than merely its founder, a primarily religious contextualization, albeit one which does not derogate from the movement's place in the history of natural science, is the appropriate one. For it is difficult to believe that the description of the cosmos which Hutchinson offered would have attracted any considerable attention, had it not been derived from the scriptural text by means of Hutchinson's reading of the Hebrew text and had it not been a vindication of trinitarian orthodoxy. Indeed, Hutchinsonianism was frequently presented without any direct reference to its cosmology. When, for example, the Bristol clergyman and schoolmaster, Alexander Catcott, felt constrained to introduce the world, or at least the city's corporation, to a system of thought which he was convinced would render impotent "the rage or subtilty" of the enemies of Christianity, he spoke not at all about the errors of Newton. The "recover[ed] knowledge of the Hebrew tongue" which he presented enabled him to demonstrate the christological and trinitarian significance of a series of biblical terms and symbols; but no disclosures of the origins and functioning of the cosmos were made. ${ }^{8}$ Religious contextualization, though, should not reduce Hutchinsonianism to a mere forerunner of the Oxford Movement, even if the emphasis placed by some studies on the Hutchinsonian "recognition of the sacramental character of the world, and of the part played by typology in Scripture" is far from being without warrant. ${ }^{9}$

4. P. B. Nockles, The Oxford Movement in Context: Anglican High Churchmanship, 17601857 (Cambridge: Cambridge University Press, 1994), 13.

5. G. N. Cantor, "Revelation and the Cyclical Cosmos of John Hutchinson," in Images of the Earth: Essays in the History of the Environmental Sciences, ed. L. J. Jordanova and R. S. Porter (Chalfont St. Giles, Bucks.: British Society for the History of Science, 1979), 1-24; C. B. Wilde, "Matter and Spirit as Natural Symbols in Eighteenth-Century British Natural Philosophy," British Journal for the History of Science 15 (July 1982): 99-131.

6. John Hutchinson (1674-1737) was a self-educated Yorkshireman who was employed as a land steward to the "proud" duke of Somerset. This nobleman acted as his patron when he set about the exposition of his biblically based cosmology and, supporting it, his interpretation of pagan religion. His works appeared between 1727 and 1732 and there was a collected edition, running to twelve volumes, published in London in 1748-9, with the title: The Philosophical and Theological Works of the Late Truly Learned John Hutchinson, Esq.

7. C. B. Wilde, "Hutchinsonianism, Natural Philosophy and Religious Controversy in Eighteenth Century Britain," History of Science 18 (1980): 1-24, is a response to this.

8. A[lexander] S[topford] Catcott, The Supreme and Inferior Elahim: a sermon preached... on ... 16th. August, 1735 ... (London, 1736). When the young William Romaine was, similarly, given the opportunity to expound the heart of the Hutchinsonian creed in sermon form, in St Paul's Cathedral in 1741, he expounded the Christian content of mankind's primitive revelation without reference to the understanding of the cosmos which was included in it. See The Whole Work of the late Reverend William Romaine . . (London, 1837), 776-84.

9. G. Rowell, “'Church Principles' and 'Protestant Kempism': Some Theological Forerunners of the Tractarians," in From Oxford to the People: Reconsidering Newman and the Oxford Movement, ed. P. Vaiss (Leominster, Heref.: Fowler Wright Books, 1996), 17-59, 22. See also A. J. Kuhn, "Glory or Gravity: Hutchinson vs. Newton," Journal of the History of Ideas 22 (July-September 1961): 303-22. See especially 317-21. 
The present study seeks to contribute to a more comprehensive description of Hutchinsonianism than has hitherto been offered and begins with the assumption that this should be primarily in religious terms. Description by reference to the parties, whose struggles to determine the definition of the Church of England have made up much of its history, is rendered difficult not merely by inconstant nomenclature but also by changing times. No particular exception need be taken to the use of the term "High Church" in referring to the Hutchinsonians. However, it should be used with a consciousness that the spectrum of positions from which it derives its meaning has by no means been static in the course of Anglican history. A temporally specific use of the term will suggest a relationship between Hutchinsonianism and Evangelicalism which elucidates the character of the former. To consideration of the situation of Hutchinsonianism in the realm of ecclesiastical politics may be added consideration of the form the movement took, which, to anticipate, is best indicated by the final words of the title of this essay.

If the description of Hutchinsonianism begins in religious terms, it should not end there: for religion is not to be treated as a separable sphere in an intellectual world which was, as Hutchinsonianism itself may be taken to illustrate, only a little less God-ridden than that described by John Redwood. ${ }^{10}$ Since discussion of the Enlightenment/Counter-Enlightenment debate provides the most inclusive map of the general intellectual life of the period - even in one about which the cartographers are not well agreed - it is this debate which will be used to locate the Hutchinsonians more precisely. The map may even be improved in the process. In particular, it is hoped that boundaries will be clarified; for with the description of Hutchinsonianism as a CounterEnlightenment movement must go some definition of this term.

In 1797 Thomas Haweis, one of the most notable Evangelicals within the late eighteenth-century Church of England, published a biography of his fellow chaplain to the countess of Huntingdon and long-time standard-bearer of the Evangelical cause in London, William Romaine. Speaking of the young Romaine at Oxford in the 1730s, he felt sure that he could have felt no inclination whatever to associate with either Dissenters or his Methodist contemporaries. For he was then among those "most bigotted churchmen, and intollerant," the Hutchinsonians, who possessed "the bitterest enmity, joined to the most sovereign contempt of all separatists from the church of England." It may indeed have been true, as Haweis also said, that the young Romaine steered clear of known Methodists on account of the opprobrium in which the university as a whole held them. ${ }^{11}$ However, the depiction of the early Hutchinsonians as exclusively Anglican and uniformly hostile to

10. J. Redwood, Reason, Ridicule and Religion: The Age of Enlightenment in England, 16601750, 2nd ed. (London: Thames and Hudson, 1996), 10.

11. Thomas Haweis, The Life of William Romaine .. . (London, 1797): 17-18, 66. 
Dissenters and as standing at the opposite pole of the ecclesiastical world from the Methodists is quite false.

Hutchinsonianism had attracted a considerable number of Dissenting adherents, some of whom, like the Independent, Samuel Pike, were competent apologists for it. The movement had followers too among members of the established Presbyterian church, ${ }^{12}$ though the most notable of these and the most lucid and convincing expounder of the doctrine, the Lord President of the Court of Session, Duncan Forbes of Culloden, is perhaps a bad example: He clearly lacked the Presbyterian zeal of his forebears. ${ }^{13}$ Among members of the established church in England Hutchinsonianism engendered not hostility, but sympathy towards Dissenters. In the case of the young George Horne this was, it seems, due to both a sense of alienation from the church's establishment in consequence of its hostility to Hutchinsonianism and a conviction that his new theology might provide the common ground on which Dissenter and churchman might "join hands against the common enemies of Christianity." Horne and his close friend, William Jones of Nayland, who stands with him as the most notable of the late eighteenth-century Hutchinsonians, only began to develop their zealous churchmanship as a result of an encounter with the writings of the Non-Jurors, in particular Charles Leslie and George Hickes, towards the end of their student days. ${ }^{14}$

A comparison with John Wesley comes easily to mind. The Wesley who arrived in Georgia was imbued with Non-Juror opinions and indeed with those of the most uncompromising Non-Jurors, the Usagers. ${ }^{15}$ His encounter, however, was with Moravians and his reading produced a real "possibility of [his] ... turning sectarian." "16 This biographical contrast neatly signifies the contrasting histories of later eighteenth-century Hutchinsonianism and Methodism. While Methodism slowly and very hesitantly moved and was pushed away from its commitment to the Establishment, Hutchinsonianism lost its Dissenting and Evangelical supporters, such as Pike and Romaine, and came to be represented by zealous churchmen, much less easily identified as Evangelicals, such as Horne and Jones. This, however, should not obscure the original homogeneity of the two movements. Even if the contemporaries who pointed out the similarities were generally those hostile to the Hutchinsonians, their observations should not be disregarded. ${ }^{17}$ Others, less engaged, also perceived the similarity. Further, the disposition of Hutchinsonian churchmen themselves towards the Methodists and other Evangelicals was clearly, if critical, nevertheless sympathetic. ${ }^{18}$

12. White: 160

13. Culloden Papers: comprising ... correspondence from the year 1625 to 1748 ... from the originals in the possession of Duncan George Forbes... [t]o which is prefixed... memoirs of the Right Honourable Duncan Forbes ... (London, 1815), i-viii, xxii. See also, Burton, 344-5. 14. William Jones, "Memoirs of the Life and Writings of Dr Horne," in The Works of the Right Reverend George Horne . . , vol. 1 (London, 1809), 57-66.

15. For the Usagers see C. D. A. Leighton, "The Non-Jurors and the Counter Enlightenment: Some Illustration," Journal of Religious History 22 (Oct. 1998): 270-86.

16. F. Baker, John Wesley and the Church of England (London: Epworth Press, 1970), 49.

17. See, for example, [John Douglas], An Apology for the Clergy ... (London, 1755), 2-3.

18. Jones, $160-8,177$. 
Perceptions of similarity no doubt often rested on little more than the ability of Hutchinsonian preachers to draw large, socially diverse congregations - particularly in London - as the young Romaine did at St George's in Hanover Square until he was ejected. ${ }^{19}$ However, this reflected more substantial similarities. The shared popularity of the Hutchinsonian and Methodist preachers rested on a shared rejection of what the Methodists were inclined to describe as the "Pelagianism" of contemporary divinity - its preference for the preaching of morality over supernatural truths. ${ }^{20}$ The Hutchinsonians' complaint was not formulated in the same way, but was, nevertheless, very similar. While Methodists contrasted the preaching of morality and the preaching of redemption in Christ, Hutchinsonians, more concerned with intellectual debate, undertook substantial refutations of natural religion. ${ }^{21} \mathrm{With}$ regard to the Hutchinsonian approach to exegesis, the foundation, as well as the mere existence of an enthusiasm for typology is noteworthy. This lay in a desire to be rid of the methods which had "flourished since the Restoration" among exegetes like Locke and Clarke, who declined to interpret the scripture in "the spirit of the Scripture," in contrast to "[t]he puritans of the last century [who] set a proper value on ... [this practice] and ... did well in displaying it."22 The more modern practice of confining attention to "the bare Letter of Scripture, interpreted according to the common Rules of speaking" was, as William Law had emphasized, extremely conducive to the abandonment or at least de-emphasizing of dogmatic truths. ${ }^{23}$ In brief, the Hutchinsonians stood solidly with the Methodists among those - and they included such notable ecclesiastics as Gibson and Secker - who were resolved to reassert against the Enlightenment's anthropocentric reductionism the necessity of "the heart's being armed with some great doctrine of salvation." ${ }^{24}$

The distance which Haweis already in the closing years of the eighteenth century supposed to exist between the High Church Hutchinsonians and the evangelical Methodists reflects a misunderstanding, increased since the Oxford Movement, of what early and mid eighteenth-century High Churchmanship was. The early eighteenth-century struggle of High Churchmanship in its political manifestation to defend the Church of England and, even more, the perception that it had failed, led, quite understandably, to a complementary or alternative strategy of "spreading... scriptural holiness through the

19. William Bromley Cadogan, The Life of the Rev. William Romaine ... (London, 1796), 1921. See also Haweis, 45-50.

20. H. D. Rack, Reasonable Enthusiast: John Wesley and the Rise of Methodism (London, 1989), 21.

21. Hutchinson himself published an attack on natural religion with the provocative title: The Religion of Satan, or Antichrist, Delineated: supposed to have proceeded from knowledge and reasoning, but proved to have proceeded from want of both. This constitutes vol. 7 of the Works. For an extended view of this topic among the Hutchinsonians, see John Ellis, The Knowledge of Divine Things from Revelation, not from Reason of Nature (London, 1747).

22. Jones, 108-9.

23. William Law, A Demonstration of the Gross and Fundamental Errors of a Late Book... (London, 1737), 5 .

24. Philalethes Oxoniensis, True Censure no Aspersion; or a vindication of . . . "A Word to the Hutchinsonians". . . (London, 1756), 14. 
land." 25 Evangelicalism might with justification be depicted as a development of or as a deviation from High Churchmanship (illustrated in Wesley's intellectual path); but it was not its antithesis. This was the Low Churchmanship of "the Latitudinarian school associated with Benjamin Hoadly and Francis Blackburne,"26 those figures who stood near or on the boundary between orthodoxy and heterodoxy in the continuum of stances which constituted the Enlightenment/Counter-Enlightenment argumentation.

If Hutchinsonianism can be identified as belonging to the same genus as Evangelicalism, within and without the Establishment, and even, in the metropolis, for a time in the 1750 s took on the appearance of something close to revivalism, it should not be concluded that this was a revivalist movement manqué. It is true that the divergence from Evangelicalism may be seen as, in a measure, adventitious. The Hutchinsonians, for example, did not possess a leadership which manifested that kind of apostolic zeal evident among the Evangelical clergy. Yet, on reflection, it appears revelatory of Hutchinsonianism's character that it was very often identified as a university phenomenon and that it was such figures as Horne who stood at the centre of it. He was certainly not the stuff revivalist leaders are made of. He emerges from his correspondence and other writings and from the recollections of his friends as an attractive character, possessed of a fine intellect and a lively sense of humour, who was complimented on his preference for laughing rather than railing at the philosophes. ${ }^{27}$ However, by his own reckoning, he possessed "a temper timid and irresolute." He did not lack measures of pastoral concern and piety, but that piety expressed itself in theological rather than pastoral zeal. Even his intimates could have observed in him little but the habitual preoccupations of the Oxford don — scholarly debates, university politics and preferments. ${ }^{28}$

The pre-eminence of dons among the Hutchinsonians suggests the appropriateness of describing their movement as an intellectual one. It is true that becoming a Hutchinsonian required serious intellectual application, particularly to the Hebrew language. Further, the master's works were all but unreadable to the uninitiated and could be approached only through introductory manuals. ${ }^{29}$ Though the simple faithful might profit from the pulpit oratory to which it gave rise, Hutchinsonianism was, at its heart, inaccessible to them - an integral defect of some seriousness if Hutchinsonianism was to become an important part of eighteenth-century revivalism. Hutchinsonianism can be described as an intellectual movement; but it was rather more. Hutchinson

25. W. R. Ward, "Anglicanism and Assimilation: or mysticism and mayhem in the eighteenth century," in Crown and Mitre: Religion and Society in Northern Europe Since the Reformation, ed. W. M. Jacob and N. Yates (Woodbridge, Suff.: Boydell Press, 1993): 81-91, 89.

26. Nockles, 32 .

27. See, for example, Bishop Samuel Halifax to Horne, 12 June 1784 (MS 471, fol. 19), Horne Papers, Magdalen College, Oxford.

28. See Horne's correspondence with the Reverend George Berkeley, the son of the philosopher bishop of Cloyne (Add. MS 39,311, passim), Berkeley Papers, British Library. The quotation is from Horne to Berkeley, 27 July 1759 (fol. 91r).

29. Horne to Rev. .. . Martin, undated (Add. MS 30,306, fol. 197v), Fairfax Correspondence, British Library. 
had not proffered a series of discrete scholarly conclusions; he had created a system of thought which provided the means to deal with the whole range of challenges with which the Enlightenment confronted religion. As one enthusiast, John Dove, put it, the Hebrew language, or rather the system of knowledge which Hutchinson had shown it to reveal,

stands as a monument of Brass or Rock of Adamant, and its infallible certainty not to be destroy'd by all the Efforts of Men, while all others must be resolved into that Confusion which gave them Birth; and while these are the Channels of all Error, that remains the source of all Truth; the Fountain from which it springs; the Point in which it centres, the Garden whence it grows, the Mine from which it must be dug, or we must go without it. ${ }^{30}$

If Hutchinsonianism required intellectual effort from its devotees, it did offer the reward of possession of a universal key of knowledge, unlocking doors closed to the members of the scholarly establishment. The undergraduate whose Hutchinsonianism allowed him to dismiss the learning of his tutors,${ }^{31}$ and the autodidact tradesman or mechanic whose enthusiasm for Hebrew etymologies could produce a system of cant and jargon which set him, at least in his own eyes, above his clergyman, ${ }^{32}$ were both characteristic Hutchinsonians.

Its capacity to refute all, or at least most, of the errors of the age ensured that Hutchinsonianism's devotees were, uniformly, zealous religionists. In consequence, Hutchinsonian analysis was the preliminary to a praxis directed to achieving change in the English church and English society. In other words, Hutchinsonianism was a reform movement. ${ }^{33}$ As Benjamin Kennicott, the distinguished non-Hutchinsonian Oxford Hebræist, observed, it was "in the honourable character of Reformers" that the Hutchinsonians themselves chose to appear. ${ }^{34}$ However, as a reform movement, Hutchinsonianism was severely circumscribed by the means with which its goals were pursued: in this its intellectual, indeed donnish, character asserted itself. The carrying of the message to the masses by those with a talent for pulpit oratory was shortlived and hardly went beyond London. As to politics, both Hutchinson himself and his followers certainly had a political position, a Tory one, and no doubt they deserve some mention among those who, around the time of the accession of George III, united Tory political theory with Hanoverian loyalty to create the most important strand in late eighteenth-century political ideology. ${ }^{35}$

30. John Dove, A Creed Founded on Truth and Common Sense ... (London, 1750), viii.

31. Thus was the young Horne. See Horne to . . 8 Nov. 1749 (Add. MS 34,079, fols. 60-1), Miscellaneous Letters, 1513-1839, British Library.

32. Jones: 52-3. See also Benjamin Holloway, The Primovity and Pre-Eminence of the Sacred Hebrew ... (Oxford, 1754): 2.

33. For the definition of this term as it is used here, see K. Hylson-Smith, The Churches in England from Elizabeth I to Elizabeth II, vol. 2 (London, SCM Press, 1997), 120.

34. [Benjamin Kennicott], A Word to the Hutchinsonians: or remarks on three extraordinary sermons ... (London, 1756): 4.

35. W. R. Ward, Georgian Oxford: University Politics in the Eighteenth Century (Oxford: Oxford University Press, 1958), 205-6; J. A. W. Gunn, Beyond Liberty and Property: The Process of Self-Recognition in Eighteenth-Century Political Thought (Kingston: McGill-Queen's University Press, 1983), 164-85; J. C. D. Clark, English Society, 1688-1832: Ideology, Social Structure and Political Practice During the Ancien Régime (Cambridge: Cambridge University Press, 1985), chap. 4, esp. 218-20. 
Political writing and preaching there was; but, apart from a zealous and religiously motivated participation in the campaign against the Jew Bill of $1753,{ }^{36}$ the Hutchinsonians showed no disposition to extend their political activity, as opposed to theorizing, beyond the clerical world. In fact, the reform which the Hutchinsonians contemplated was, before all else, a reform of the clergy. It is certainly at once noticed that easily the most frequent complaint levelled against the Hutchinsonians of the 1750s was that they engaged in too virulent a criticism of the clergy. Kennicott accused them of maintaining "that most other Divines are wicked and profane in their Conduct - or, corrupt in their explanations of Christianity — or, in reality, Unbelievers of Revelation or, at best, miserably mistaken in their notions of true Philosophy." 37 This was, no doubt, a more effective criticism than engagement with Hutchinsonian scholarship in what was, in fact, an exercise in university politics. Still, it makes it clear enough that Hutchinsonian reform's goals can, not altogether wrongly, appear to have been very restricted indeed, often merely to the clergy's intellectual life.

This may seem to preclude taking Hutchinsonianism seriously as a reform movement. However, the not unfounded convictions of the age about the role of the clergy in society and the capacity of doctrine to determine human behaviour should be kept in mind - not to mention the convictions of the two English universities about their ability to shape the nation's life. Moreover, as the following section of this study, it is hoped, makes clear, the intellectual reform envisaged provokes an interest by virtue of its content. For it offered a profound challenge to that eighteenth-century "holy alliance" of trends in Anglican thought and the English Enlightenment, or more particularly the new science - an alliance which was dangerous and difficult enough in the eighteenth century and ultimately proved so disastrous to an Anglicanism incapable of resting its apologetic on the newer science of the following century. ${ }^{38}$

\section{II}

The concept of such an alliance might be taken as supportive of the broader concept, notably advanced by J. G. A. Pocock, of an English Enlightenment characterized as conservative by virtue of its utilization by contemporary, particularly clerical elites. English moderation, in an "enlightenment sans philosophes," emerges in flattering contrast to the foreign militancy of the "crusade against Christianity." ${ }^{39}$ Such a contrast cannot be sustained. Neither

36. White, 158; Cadogan, 25-6.

37. [Kennicott], 19.

38. J. Gascoigne, Cambridge in the Age of the Enlightenment: Science, Religion and Politics from the Restoration to the French Revolution (Cambridge: Cambridge University Press, 1989); M. C. Jacob, The Newtonians and the English Revolution, 1689-1720 (Hassocks, Sus.: Harvester Press, 1976), 16.

39. J. G. A. Pocock, "Post-Puritan England and the Problem of the Enlightenment," in Culture and Politics from Puritanism to the Enlightenment, ed. P. Zagorin (Berkeley and Los Angeles: 
England nor even the Protestant world as a whole was singular in possessing elites, including clerical elites, willing to utilize Enlightenment notions in defence of their beliefs. There was, after all, a Catholic Enlightenment, though Peter Gay preferred to speak of it as "the treason of the clerks" and the "suicidal conduct" of the clergy in attempting to accommodate their religion to beliefs created or shaped by hostility to it. ${ }^{40}$ This view has the merit of agreeing with the mainstream of Catholic — and anti-Catholic — thought in the nineteenth and most of the twentieth century. However, Gay's judgment that the edifice of compromise was raised on sand, if nothing else, blinded him to the skill and indeed genius of some of the builders and led him to ignore their achievement.

The depiction of England's moderate Enlightenment tends to the opposite extreme. It is well, for example, to acknowledge the importance which the new science and Anglican thought had for each other; but well also to recall that the "holy alliance" was binding on neither all practitioners of the former nor the whole Church of England. The pervasiveness attributed to the moderate Enlightenment suspiciously mirrors in intellectual history the attributions of stability to the Whig state and near universal approbation of its ideology, which, to say the least, are now less than convincing to political historians. An emphasis on conflict rather than consensus is more congruent with a perception of the depth of that fear of the threats to Christianity, which Redwood has convincingly depicted as the driving force of Enlightenment/CounterEnlightenment conflict. ${ }^{41}$ It was a fear which bred militancy in orthodox Christianity's defenders. The Arians and Socinians of the eighteenth century may not now be remembered in the same thought as Voltaire and Diderot, but they were, as Nigel Aston remarks, the philosophes that England had ${ }^{42}$ and they provoked just as much hostility and of a very similar kind among many, as their continental counterparts - and they — did in the mind of Burke. $^{43}$

In other words, there was an English Counter-Enlightenment and, it should be added, it is more deserving of study, as the phenomenon less likely to be well understood in the present age, and consequently perhaps more thoughtprovoking, than the set of beliefs it struggled against. Pocock renders this study unnecessarily difficult, firstly by appropriating the most conspicuous characteristic of the Counter-Enlightenment, its defence of orthodox Christianity, for

University of California Press, 1980), 91-111, 92-3. See also his "Conservative Enlightenment and Democratic Revolutions: The American and French cases in British perspective," Government and Opposition 24 (1989): 81-105.

40. P. Gay, The Enlightenment: An Interpretation: The Rise of Modern Paganism, vol. 1 (New York: Alfred A. Knopf), 343, 351.

41. See the work cited in footnote 10, above.

42. N. Aston, "The Dean of Canterbury and the Sage of Ferney: George Horne Looks at Voltaire," in Jacob and Yates, eds., 142.

43. For examples of the perception of Socinian conspiracy and its relationship to the conspiracy of the troupeau des philosophes, see George Horne, The Duty of Contending for the Faith: a sermon preached at the primary visitation of the Most Reverend John [Moore], Lord Archbishop of Canterbury, in the cathedral ... on ... July 1, 1786 ... 2nd ed. (London, 1787), 11-12, and Henry Kett, History the Interpreter of Prophecy... vol. 3 (Oxford, 1799), 64. 
a conservative Enlightenment. Further, in harmony with his emphasis on the singularity of the English Enlightenment, the orthodoxy of which he speaks is a complex Anglican one, with its various concerns to repel the several enemies of the Church of England. ${ }^{44}$ Pocock's conservative Enlightenment can easily be given the name with which Gay categorizes the corresponding French phenomenon.

If the concept of the Enlightenment is to be kept, rather than dissolved into eighteenth-century intellectual history, then the debate of which it was a part should be neither obscured nor fragmented. There is merit in retaining a more traditional, simpler, and more flexible view than Pocock's, one which preserves a focus on a pan-European conflict between orthodox Christianity and individualistic rationalism. This need not produce oversimplification. It may and should be acknowledged that between the two extremes of usually merely imaginary, rationalistically generated atheism and orthodox Christianity, there was a vast spectrum of intermediate positions, always open to attack from both sides; that the debate proliferated luxuriantly through almost every field of scholarly inquiry; that the threat to the dogmatic structure which the common rationalist heresy posed varied from one confessional body to another; and that this conflict with this heresy was about the social as well the epistemological location of authority. ${ }^{45}$ Some of this complexity is illustrated with reference to Hutchinsonianism below. Nevertheless, one should not lose sight of the wood. As the variety of debates and positions are commented on, it should still be made clear, as Redwood has illustrated, that we are observing parts "of one ... debate about the defence of the true nature of a Christian community." 46 The category of "Counter-Enlightenment" may be applied to those positions in this debate which defended ecclesiastical authority and the orthodoxy which issued from it, ultimately on the basis of an epistemological decision in favour of an alternative to individualistic rationalism.

Hutchinsonianism fits extremely ill with Pocock's categories. At first sight, it appears as a decided rejection of any participation in a conservative Enlightenment. It is above all Newtonian science which has been pointed to as having provided the enlightened content of the stances adopted with conservative purpose in the distinctively English Enlightenment: and it was Newton who was Hutchinson's bette noir ${ }^{47}$ The disciples, in fact, tended to a more moderate view on Newtonianism than the master: Horne held that Newton's and Hutchinson's views might be regarded as complementary. ${ }^{48}$ Probably rather more shocking to clerical contemporaries was the Hutchinsonian rejection of natural theology. When Thomas Patten of Corpus Christi College, Oxford,

44. J. G. A. Pocock, "Within the Margins: The Definitions of Orthodoxy," in The Margins of Orthodoxy: Heterodox Writing and Cultural Response, 1660-1750, ed. R. D. Lund (Cambridge: Cambridge University Press, 1995), 33-53.

45. J. A. I. Champion, The Pillars of Priestcraft Shaken: The Church of England and its Enemies, 1660-1730 (Cambridge: Cambridge University Press, 1992), 10.

46. Redwood, 11.

47. Hutchinson's anti-Newtonian polemic is most clearly displayed in his Treatise of Power Essential and Mechanical..., which constitutes vol. 5 of the Works.

48. Horne, Works, vol. 6, 113-77. 
indicated his sympathy with this Hutchinsonian stance and others, his critics, who had concluded falsely that he was a devotee of Hutchinson, accused him of a desire "to destroy Human Reason and the Powers thereof." ${ }^{49}$ Rather more profound was the Hutchinsonian dependence on analogical thought. The rejection of the Renaissance enthusiasm for analogy was a foundation of the new science. The individualistic creation of images, subject to no external control, stood in clear opposition to public, rational discourse. The subjection of extramental reality to the private language of analogy rendered it chaotic. ${ }^{50}$ It was an immense trinitarian analogy which was "the core of the Hutchinsonian system" of cosmology ${ }^{51}$ and the whole primitive revelation in which this had been disclosed was "Christianity in type." 52 It was not merely that Hutchinsonianism challenged specific teachings of the noted figures of the English Enlightenment, but rather that it presented anew — and for many convincingly - a mode of thinking, the rejection of which was fundamental to that Enlightenment.

Yet, in truth, even in the shallowest of entries into the Hutchinsonian writers, the reader is aware of being, in many respects, in the familiar environment of English Enlightenment thought. If Locke would have found Hutchinsonian analogical thinking repugnant, he would also have found enthusiasm for his rejection of innate ideas. If God had chosen to reveal Christian dogma through the constitution of the Hutchinsonian cosmos, then there was clearly no need for "immediate Ideas of spiritual Things or the invisible world, [and the notion of] our Ideas being admitted only through the Inletts of our Senses" was a perfectly acceptable one. ${ }^{53}$ This element of Lockean epistemology was not merely congruent with Hutchinson's system. For the Hutchinsonians as much as for others it served that English Enlightenment preoccupation with the repelling of enthusiasm. ${ }^{54}$ Even the argument of Patten, shocking as its rejection of natural theology may have been, could have been supported with ample Latitudinarian citation. What Patten strove to do was not, of course, "to destroy Human Reason," but to ensure that theological reason was permitted to operate only when the datum of the discipline, revealed truth, had been accepted. This, though, was the "truth of facts," that is, historical facts, vouched for by miracles. Patten was more inclined to cite Charles Leslie than

49. Ralph Heathcote, The Use of Reason Asserted in Matters of Religion . . (London, 1756), 4. Thomas Patten (1714-90) was a well-respected and fairly senior university figure. He entered into controversy with the younger Heathcote, having just taken his doctorate in 1754 . He was later rector of Childrey in Berkshire.

50. B. Vickers, "Analogy Versus Identity: The Rejection of Occult Symbolism, 1580-1680," in Occult and Scientific Mentalities in the Renaissance, ed. B. Vickers (Cambridge: Cambridge University Press, 1984), 95-163.

51. Wilde, 4.

52. [Robert Spearman], Letters to a Friend concerning the Septuagint Translation and the Heathen Mythology (Edinburgh, 1759), 68.

53. Dove, Creed, 5. Hutchinsonian rejection of innate ideas is frequently expressed. See, for further exemplification, Catcott, 5-6. For a more substantial statement of the acceptance of Locke's epistemology, in this case combined with a rejection of his natural theology, see [John Ellis], Some Brief Considerations upon Mr Locke's Hypothesis, that the Knowledge of God is Attainable by Ideas of Reflection... (London, 1748).

54. John Dove, Rational Religion, Distinguished from that which is Enthusiastic ... (London, n.d.), 15-16. 
the Latitudinarians in support of this view ${ }^{55}$; but it was, as Robert Pattison has pointed out, also an entirely conventional Latitudinarian depiction of revelation - one which could be, and later was, productive of a most destructive rationalism. ${ }^{56}$ On the whole, one may be inclined to conclude that there was rather more conservatism and rather less Enlightenment about Hutchinsonianism, but there is enough of the latter Hutchinsonianism to render clear statement difficult.

The concept of a conservative Enlightenment does little to aid the understanding of Hutchinsonianism, which can be placed neither within nor without its bounds. However, if the traditionally understood Enlightenment/CounterEnlightenment debate, with an epistemological concern at its centre, is retained, a helpful brief description of Hutchinsonianism is provided. The phenomenon of Hutchinsonianism also illustrates the debate as a spectrum formed by a varying understanding of what it was necessary to concede in establishing an effective defence of Christianity and, further, illustrates the use in the debate of a variety of fields for conflict. Attention to this last point calls for comment on a neglected aspect of Hutchinsonianism.

Hutchinsonianism may be said to have grown out of two distinct, though related, seventeenth- and early eighteenth-century fields of scholarly debate - cosmology and the history of religion — and it devoted just as much attention to the latter as to the former. ${ }^{57}$ The mind of learned Europe in the era of the Renaissance and after had become anxiously aware of the variety of human religion, as the distant past and distant lands were explored. With the difficulty of accommodating this new information within a scriptural frame of mind, there was an inevitable turning to polygenetic explanations of human origins and the field became at length a playground for Deists seeking to discover empirically the elements of their natural religion or to demonstrate that the origins of religion lay in fraud. Before this, however, writers such as Louis Thomassin in the Catholic world, Gerard Vossius in the Netherlands, and Ralph Cudworth at Cambridge made valiant and monumental efforts to relate the new information to scriptural knowledge and indeed use it to display a primal, prophetic revelation of Christianity. ${ }^{58}$ It is in this tradition that Hutchinsonianism clearly stands, though Hutchinson was probably obliged to later writers, such as the High Church sacramentologist, John Johnson of

55. Thomas Patten, A Sermon Preached before the University of Oxford... July 13th., 1755, 3rd ed. (Dublin, 1756), 12. For the influence of Leslie, see Thomas Patten, St Peter's Christian Apology ... (Oxford, 1756), 74-5 and The Sufficiency of External Evidence of the Gospel further Supported ... (Oxford, 1757), 63.

56. R. Pattison, The Great Dissent: John Henry Newman and the Liberal Heresy (Oxford: Oxford University Press, 1991), 79-85.

57. Hutchinson himself may be said to have had a greater interest in cosmology. His views on the history of religion are to be found throughout his works. However, A New Account of the Confusion of Tongues.... and The Covenant of the Cherubim ... (in vols 4 and 7 of the Works respectively) are his chief pieces on the subject.

58. P. Harrison, "Religion" and the Religions in the English Enlightenment (Cambridge: Cambridge University Press, 1990). See also R. H. Popkin, "The Crisis of Polytheism and the Answers of Vossius, Cudworth, and Newton" and "Polytheism, Deism, and Newton," in Essays on the Context, Nature, and Influence of Isaac Newton's Theology, ed. J. E. Force and R. H. Popkin (Dordrecht: Kluwer, 1990), 9-25 and 27-42 respectively. 
Cranbrook. Johnson, like Hutchinson and his followers, laid particular stress on the place of sacrifice, as a prophecy of Christ's sacrifice, in the primal revelation and made free use of reference to pagan sacrificial practices in his works. ${ }^{59}$ He also depicted written Hebrew as having a special role in the transmission of this revelation and as having been, in consequence, perversely distorted by the Jews. ${ }^{60}$

If Hutchinson's opinions about cosmology and the history of religion were originally distinct, he succeeded in welding them together thoroughly in his new system, which taught that

[t]he patriarchs and believers made that use of the knowledge of nature designed by him who gave it to them; they regarded it as a ladder, whereby they might ascend to a knowledge of the almighty Lord of nature, and his spiritual operations in the œconomy of redemption. But the nations, after their apostacy at Babel, dropt the originals, and worshipped the copies instead of them, serving the creatures more, or rather than the creator. ${ }^{61}$

Julius Bate, Hutchinson's most devoted disciple, ${ }^{62}$ acknowledged that if it could be shown that ancient heathen religion was not the perverted worship of the cosmological forces described and shown to be symbols of the Trinity by Hutchinson's reading of the Hebrew scripture, then "indeed a Cornerstone, a main Pillar" of Hutchinsonianism would be removed and "the whole Building would totter."63

This ingenious taking up of the notion that paganism was the worship of natural forces and combining it with the notion that it was the distorted remains of a prisca theologia was original enough and offers a good example of the way in which Hutchinsonianism could appeal with a striking comprehensiveness of explanation. However, it was not merely in its combination of elements that Hutchinsonianism's advance from its sources was shown. While earlier systems had combated existent or potential attacks

59. [John Johnson], The Propitiatory Oblation of the Holy Eucharist Truly Stated, and Defended ... (London, 1710), 121. See also, for examples of his use of the idea, The Theological Works of the Rev. John Johnson, M.A., Vicar of Cranbrook, in the Diocese of Canterbury, ed. $\mathrm{R}$ [obert] $\mathrm{O}$ [wen] (Oxford, 1847), 1: 74-9, 81; 2: 47-53. For the importance of the notion in Hutchinsonianism, see the sermon of Romaine cited in footnote 8 , above.

60. Thomas Brett, The Life of the Late Reverend John Johnson . . . : together with three of Mr Johnson's posthumous works ... (London, 1748), 269-71, 295-6. For the possibility of Hutchinson having had access to this material, see 211 .

61. William Dodd, trans., The Hymns of Callimachus . . . (London, 1755), unpaginated preface. This work was produced while the young Cambridge man was still an enthusiastic Hutchinsonian. The texts of Callimachus offered an excellent opportunity to present, as a series of annotations, Hutchinsonian interpretations of Greek mythology. Dodd later turned against Hutchinsonianism. See his Conference between a Mystic, an Hutchinsonian, a Calvinist, a Methodist, a Member of the Church of England and Others ... (London, 1761), 17-32. The preface was actually mostly written by Horne and presents an admirably concise statement of the Hutchinsonian understanding of the history of religion. See Jones, 47.

62. Bate (1711-71) was educated at St John's, Cambridge. As a result of his friendship with Hutchinson, he obtained the living of Sutton, near Petworth, the duke of Somerset's seat in Sussex. With Robert Spearman he was responsible for the publication of the collected edition of Hutchinson's works.

63. Julius Bate, A Defence of Mr Hutchinson's Tenets in Philosophy and Divinity: in answer to the objections of Mr [Simon] Berington (London, 1751), 3. 
on Christianity in general and trinitarianism in particular, Hutchinsonianism showed a marked ability to mould itself to deal with what the mid-eighteenthcentury defenders of these positions perceived as the most pressing threats, while also presenting itself in a way that was likely to appeal to minds which had already been shaped by at least the commonplaces of the early Enlightenment. In other words, it illustrates well that process of conflict which created the spectrum of argumentation which was English Enlightenment/CounterEnlightenment debate. There were hostilities, directed to close and more distant positions, but also concessions, made out of necessity or the desire for persuasiveness.

Though there may not have been "more than a handful of deists . . . at the time of the Glorious Revolution," 64 it was clear around the middle of the following century that, despite the intellectual weakness of their belief before and certainly after Butler, Deists were now more numerous. Consequently, Hutchinson and his followers were by no means disposed to allow their central assertions - that both cosmology and the history of religion displayed the truth of the Christian revelation - to serve as their only weapons against the enemy. Any part of the Hutchinsonian system was likely to be utilized against Deism and particular Deist arguments. Thus, the concept of a primitive revelation was not merely asserted and defended; but it was also elaborated into a narrative of conflict with Deism, explicitly so named, which was the sin of the Fall, when man had been lured by a desire for "an Equality of Understanding with the supreme Powers. The Consequence of this, they knew, would be Independency, and a Right to examine the Reasonableness of the Law of God." ${ }^{\prime 65}$ Deism was no passing phenomenon. It was elevated to the status of a cosmic evil. This view was strikingly appealing to those who, at the end of the eighteenth and the beginning of the nineteenth century, perceived the power of Antichrist in the Enlightenment-inspired revolution in France. ${ }^{66}$ Again, the Hutchinsonian interest in the history of religion was turned to good use in replying to the Deist protest against the injustice of a revelation which was not universal, ${ }^{67}$ though they also argued in more abstract terms, pointing out, anticipating views that became common later, that reason was not available as a foundation of belief to the mass of humanity, who perforce were guided by tradition and authority. ${ }^{68}$ In addition to asserting that "[r]eligion was twice universal" (at Creation and after the Flood), ${ }^{69}$ the Hutchinsonians held not only that the primitive revelation endured among many individuals outside of the believing Israelite or Jewish communities, but also that pagan

64. Popkin, "Polytheism, Deism, and Newton," 27.

65. Walter Hodges, Elihu: or an enquiry into the principal scope and design of the Book of Job (London, 1750), ix.

66. See especially William Van Mildert, An Historical View of the Rise and Progress of Infidelity: . . . in a series of sermons preached for the lecture founded by the Hon. Robert Boyle ... from the year 1802 to 1805 , 4th ed., 2 vols. (London, 1831).

67. For this, see D. Brown, "Butler and Deism," in Joseph Butler's Moral and Religious Thought, ed. C. Cunliffe (Oxford, Clarendon Press, 1992), 7-28, 10-13.

68. The Whole Works of the Right Honourable Duncan Forbes..., vol. 1 (Edinburgh and London, n.d.), 22-4.

69. Hodges, xvi. 
religion retained from its revealed original a sufficiency of truth to guide the well disposed. ${ }^{70}$

Most, however, were not well disposed. Again and again the Hutchinsonians argued that it was sinful motives that had led to the rejection, throughout history, of the true revelation, which "flattered not ... pride and vanity, but tended to lower the pretensions of human wisdom, and pull down the lofty systems, which presumptious imagination had set up." "T1 This insistence on the voluntary nature of faith and the consequent culpability of unbelief struck at many more than the Deists, for it struck against the underpinnings of the period's very hesitant acceptance of religious toleration. In truth, the Hutchinsonians were less interested in assaulting "Infidels declar'd" than

the covert Sort of Wideners; who herd with Believers, and pretend themselves to be Believers, and take Posts and Places in the Church as Believers, but in their Writings and Discourses, by two-fac'd Glosses on the Scriptures, they are every day slily giving up one Point, or another, of the Faith, to Infidels.

There were also those who

talk of Moderation, Meekness, Charity, or Benevolence; with some other excellent moral, and divine Virtues. But, while they pretend also to some dreadful Apprehensions from the Works of a false Zeal; they divest themselves altogether of the true; and talk of the holy Mysteries of Faith, as of Things indifferent, uncertain, obscure, unreasonable ... not fit to be contended for! ${ }^{72}$

Indeed, it was the merit of the broadening of the attack on Deism that any tendency to rationalism in these positions nearer to Hutchinsonianism on the spectrum of Enlightenment/Counter-Enlightenment argumentation could be used to blacken the fools and knaves by association.

However, the Hutchinsonian position was shaped not only by the confrontations of the Enlightenment/Counter-Enlightenment debate, but also by its persuasions. The epistemological centre of the debate, the rationalist challenge, showed itself, inevitably in Protestant Britain, most clearly in the field of biblical exegesis. A number of the most zealous defenders of individualistic rationalist interpretation, such as Samuel Clarke and William Whiston, stood, with historical appropriateness, for Arianism. For Arianism had insisted on the use of biblical language, while their opponents had asserted the authority of the church, having been "driven to the realization that the deepest questions which face Christianity cannot be answered in purely biblical language, because the questions are about the meaning of biblical language itself." 73 Eighteenth-century Arians, able to use the Protestant sola scriptura slogan, found themselves at an advantage in presenting their views. Their opponents were driven to two unpleasant alternatives. The first, a plain rejection of the

70. See, for example, [Spearman], 69-76.

71. Van Mildert, vol. 1, 134-35.

72. Holloway, xxix-xxx.

73. R. P. C. Hanson, The Search for the Christian Doctrine of God: The Arian Controversy, 318-381 (Edinburgh: T.\&T. Clark, 1988), xxi. 
right of private judgment, smacked too much of popery, though some, like the Usagers, made the attempt, reposing authority in the Early Church. ${ }^{74}$ Equally unpalatable was the enthusiastic alternative, embraced by William Law, who was willing to repose authority in the inspired Jacob Böhme. ${ }^{75}$ It might be said that, in reality, the Hutchinsonians reposed authority in the inspired John Hutchinson — as some anti-Hutchinsonians suggested. ${ }^{76}$ However, the Hutchinsonians themselves chose to present their views in a way which indicated a solid adherence to Protestant principles and a disdain for private revelations.

If other Hutchinsonians were not so guarded, Horne at least constantly made it clear that he regarded Hutchinson as merely a scholar among others, and whose opinions were to be judged by the usual scholarly criteria and adopted selectively. ${ }^{77}$ Horne's attitude to enthusiasm emerges most clearly in his violent denunciations of Law's Behmenism and of Swedenborg. His objections, though perhaps sharpened by a feeling that Law had betrayed the High Church cause, might have been those of any Latitudinarian. Why, he asked, if this was not a new revelation, was Böhme's interpretation of scripture "wrapt up in such mystic jargon ... and not given us in Scripture language, which is the only explainer of itself?"78 Even more removed from the attitude of those who sought authority outside scripture was his assertion that "the Scripture is clear and uniform in its language, as coming all of it from the same author, and addressing itself to the capacity of all mankind.,"79 In brief, the Hutchinsonians were content to meet their enemies on their own sola scriptura ground and fight with the rationalist weapons they had chosen.

Having in view this failure to fight the most important application of those notions which, it is contended here, should be taken as lying at the heart of the Enlightenment challenge, it seems difficult to classify Hutchinsonianism as a true Counter-Enlightenment movement. It inherited important elements of Latitudinarian thought in both philosophy and theology and was very preoccupied indeed with the argument for Christianity from universal consensus - an argument which, quite understandably in view of the uses that were made of it, was regarded as dangerous to religion. ${ }^{80}$ If to this is added an unclear stance on the role of individualistic rationalism, one which did not come to grips with the central matter and merely sought to ensure that trinitarian orthodoxy was saved from its ravages, clear classification does indeed seem to become difficult.

However, the categorization of Hutchinsonianism as a Counter-Enlightenment movement should be allowed to prevail. What is being discussed is a

74. See the reference in footnote 15 , above.

75. See C. D. A. Leighton, "William Law, Behmenism and Counter-Enlightenment," Harvard Theological Review 91 (1998): 301-20.

76. See, for example, Heathcote, 84-5.

77. See, for example, Horne, Works, 6: 187-89.

78. Horne, 1: 209.

79. Horne, 1: 222 .

80. O. Chadwick, From Bossuet to Newman: The Idea of Doctrinal Development (Cambridge: Cambridge University Press, 1957), 56-7. 
spectrum of argumentation and it is not necessary to show that Hutchinsonianism occupied the most extreme position on it. It may be readily conceded that Counter-Enlightenment apologists were capable of positive responses to positions more commonly associated with thinking they habitually deplored. More important in the matter of classification is the intention with which the Hutchinsonians adopted their positions and that was clearly the defence of Christian orthodoxy. The willingness of Horne, referred to above, and other Hutchinsonians to declare for firm adherence to the Sixth Article and to accept rationalist criticism of scripture seems to constitute a more serious objection to a simple classification of Hutchinsonianism as a Counter-Enlightenment movement. However, this agreement of the Hutchinsonians with their opponents was more apparent than real. The latter accepted scripture not as an alternative to individualistic rationalism, but as subject to its scrutiny and thus subordinate. For the Hutchinsonians, scriptural revelation could be seen to produce a far more convincing picture of the world's structure and history than the feeble human mind. That the Enlightenment's rationalism was admitted at all was due only to the belief that John Hutchinson had rendered the scripture impervious to its assaults. If the Hutchinsonians' predecessors, the Non-Jurors and particularly the Usagers and William Law, have figured far more prominently in accounts of eighteenth-century British religion, this is just. For they showed an appreciation very quickly that the citadel of scripture had been overrun and that the defence of orthodoxy against individualistic rationalism would have to be conducted on other ground. 